\title{
Pertanian Biodinamik: Studi Kasus Sistem Produksi Anggur Alternatif di Ihringen, Jerman Selatan
}

\author{
Lara Wilis \\ Alumni Departemen Antropologi, Universitas Gadjah Mada \\ Email: wilisnagasasra@gmail.com
}

\begin{abstract}
Agricultural industrialization in Germany is characterized by the use of chemical inputs, agricultural mechanization with the aim of productivity and efficiency. The environmental impact of industrialization is reduced soil fertility and biodiversity. On the other hand, agricultural industrialization has pushed small-scale farming businesses out of the agricultural sector since they are unable to compete as industrial farmers. Sustainable farming practices began to emerge as a counter movement. This system rejects the use of chemical inputs and upholds environmental sustainability with the expectation that it can also increase the farmers' prosperity by cutting commodity chains. In the midst of high market competition, in the village of Ihringen, Southern Germany, which is known as a wine-producing region, there is a biodynamic small-scale farming business. This farming practice is an eco-friendly agriculture which is considered a bit mystical due to the lunar calendar guidance and specific farming systems with biodynamic preparations (biodynamische präparate) are believed to be able to link cosmic energy with agriculture. This practice is believed to optimize food quality. In practice, small-scale biodynamic farming is not ideally applied due to farmers still facing the market competitiveness challenges.
\end{abstract}

Keywords: small-scale farming, eco friendly wine, biodynamic wine, Ihringen

\begin{abstract}
Abstrak
Industrialisasi pertanian di Jerman diwarnai dengan penggunaan input kimiawi, mekanisasi pertanian dengan tujuan produktivitas dan efisiensi. Dampak lingkungan industrialisasi adalah berkurangnya kesuburan tanah dan biodiversitas. Di sisi lain industrialisasi pertanian mendorong usaha tani skala kecil keluar dari sektor pertanian karena tidak mampu berkompetisi sebagai petani industrial. Praktik pertanian berkelanjutan mulai muncul sebagai gerakan tandingan. Sistem ini menolak penggunaan input kimiawi dan menjunjung tinggi keberlanjutan lingkungan dengan harapan juga dapat meningkatkan kemakmuran petani dengan pemotongan rantai komoditas. Di tengah kompetisi pasar yang tinggi, di Desa Ihringen, Jerman Selatan, yang dikenal sebagai wilayah penghasil anggur terdapat usaha tani skala kecil biodinamik. Praktik pertanian ini adalah pertanian ramah lingkungan yang
\end{abstract}


dianggap agak mistis karena panduan kalender rembulan dan sistem pertanian yang spesifik dengan preparasi biodinamik (biodynamische präparate) diyakini mampu menghubungkan energi kosmis dengan pertanian. Praktik tersebut dipercayai dapat mengoptimalkan kualitas pangan. Pada praktiknya pengusahaan tani skala kecil biodinamik ini tidak diterapkan secara ideal karena petani masih berhadapan dengan tantangan kompetitivitas pasar.

Kata Kunci: usaha tani skala kecil, anggur ramah lingkungan, anggur biodinamik, Ihringen

\section{Pendahuluan}

Industrialisasi pertanian di Jerman telah mengubah pertanian skala kecil menjadi bisnis raksasa. Akibatnya tenaga kerja petani terdorong untuk masuk dalam sektor industri pertanian skala besar. Jumlah petani dan rumah tangga petani terus menurun sejak tahun 1900-an. Menurut catatan Gruner Bericht (1956-70); Agrarbericht (1971-97) angka orang yang bekerja di sektor pertanian Republik Federal Jerman (FRG) sejak tahun 1949 yakni 5,3 juta orang terus mengalami penurunan menjadi 0,69 juta orang di tahun 1994 (dalam Wilson dan Wilson, 2001: 34). Industrialisasi pertanian yang dilakukan untuk meningkatkan daya saing hasil pertanian di perdagangan internasional ini ditopang oleh negara. Negara mengerahkan dana dan membuat kebijakan pertanian dimana petani didorong untuk melakukan pengusahaan pertanian dengan lahan yang lebih luas. Hal ini juga ditunjang dengan pembangunan infrastruktur seperti sistem pengairan, perbaikan jalan dan bangunan. Intensifikasi pertanian membutuhkan biaya yang besar dan petani tidak mampu melakukannya tanpa dukungan insentif dari negara. Sektor pertanian dinilai tidak efisien dalam memanfaatkan lahan, tenaga kerja serta kapitalnya. Gelontoran insentif telah diberikan pada petani dan mesin-mesin modern sudah digunakan untuk meningkatkan produktivitas, hanya saja mesin mahal masih tidak memaksimalkan hasil tani. (Mayhew, 1970).

Pada dekade 1970-an di Jerman, petani merasakan situasi tuntutan daya saing pasar. Kerusakan akibat Perang Dunia II mendorong masyarakat untuk membangun kembali ekonomi mereka. "Setelah perang, suasana hati petani dipenuhi dengan keinginan untuk mendapatkan uang dan uang." Ungkap Gisela, seorang petani anggur di Desa Ihringen, Kaiserstuhl, Jerman Selatan. Intensifikasi pertanian adalah salah satu cara yang dilakukan oleh para petani untuk meningkatkan jumlah produksi anggur melalui input kimia, mekanisasi pertanian dengan tenaga manusia menjadi tenaga mesin, penggunaan bibit unggul dari proses hibrida; serta herbisida, pestisida dan fungisida untuk mengatasi hama dan penyakit. Gisela mengungkapkan,

\footnotetext{
"Pertanian semacam itu, atau pertanian konvensional, membuat orang tidak bisa menikmati kehidupan mereka. Apabila tanaman dipaksa untuk memproduksi lebih banyak buah, ia tidak akan mampu melawan hama penyakit. Sama seperti petani yang dipaksa terus bekerja. Baik petani dan tanaman membutuhkan tidur dan istirahat yang cukup." (wawancara, Desember 2018)
} 
Gisela adalah seorang petani yang menolak praktik-praktik pertanian dan pengusahaan anggur konvensional. Sebagai gantinya, ia melakukan pengusahaan anggur ramah lingkungan atau 'organik'. Praktik pertanian organik adalah dengan menolak penggunaan bahan kimia. Minat akan pengusahaan anggur ramah lingkungan tumbuh untuk membangun kerja yang aman dan berkelanjutan. Praktik pengusahaan anggur organik membawa usaha anggur keluarga pada praktik biodinamik yang menerapkan pentingnya aspek kosmologi. Penerapan sistem pertanian biodinamik dibarengi dengan kepercayaan praktisinya atas kekuatan kosmis yang disebut mampu mengoptimalkan kualitas hasil pangan. Tidak semua petani setuju akan hal tersebut, sistem biodinamik dianggap sebagai sistem yang aneh. Seorang petani konvensional mengungkapkan, "Tidak ada bedanya pertanian ramah lingkungan dengan pertanian konvensional. Yang berbeda hanyalah apa yang ada di kepala mereka [petani biodinamik]“ (wawancara, Februari 2019).

Pertanian ramah lingkungan dengan praktik biodinamik menuntut waktu kerja yang lebih banyak untuk melakukan perawatan tanaman. Dalam situasi ini, pengusaha anggur mencoba untuk meningkatkan kualitas anggurnya di tengah tuntutan biaya produksi dan kompetitivitas pasar. Terdapat berbagai respon terhadap cara memproduksi anggur biodinamik. Meskipun dianggap memiliki kualitas tinggi dan reputasi yang baik, beberapa pihak masih memandang bahwa cara ini bukanlah cara yang menguntungkan. Bertolak dari persoalan tersebut, artikel ini mencoba untuk menjawab pertanyaan: mengapa petani melakukan pertanian biodinamik meskipun dibutuhkan lebih banyak tenaga kerja dalam praktik tersebut?

Artikel ini menjawab pertanyaan tersebut dengan membahas mengenai pilihan pengusaha anggur untuk mengubah sistem produksi anggur organiknya menjadi sistem biodinamik, merujuk pada wacana pertanian ramah lingkungan serta deskripsi atas praktik pengusahaan anggur biodinamik. Metode penelitian yang saya gunakan adalah etnografi dan studi literatur.

\section{Pertanian Anggur : Interaksi Manusia dan Alam dalam Aktivitas Ekonomi}

Usaha produksi anggur ramah lingkungan dipandang memiliki dasar ideologis mengenai pengaruh non-manusia terhadap kehidupan manusia dan alam. Di sisi lain, praktik produksi tersebut juga menerapkan beberapa aktivitas atau ritual yang dianggap mistis oleh masyarakat. Geertz, Turner, dan Douglas (dalam Segal 2010) menerangkan bahwa ritual memiliki fungsi untuk menjunjung tinggi masyarakat memberikan manusia tempat untuknya dan juga semestanya. Ritual juga menggambarkan bentuk simbolik dan nilainilai pokok serta orientasi kultural (Turner dalam Segal 2010).

Di sisi lain, pengusahaan anggur ramah lingkungan tidak dapat dilepaskan dari perbincangan mengenai ekonomi neoliberalisme dimana konsumerisme menjadi corak utamanya (Guthman 2008). Guthman (2004) mengemukakan bahwa pertanian organik yang semestinya memberikan jalan bagi petani untuk dapat beraktivitas ekonomi secara berkelanjutan (baik ekonomi maupun lingkungan), namun pada prakteknya justru menyerap keuntungan dari petani melalui sistem pelabelan "bio" dalam pangan yang dihasilkan.

Sebagaimana industri minuman beralkohol di Eropa telah didorong oleh kebijakan 
di Uni Eropa yang mampu meningkatkan pendapatan negara karena mampu menarik konsumen internasional (Mercile 2016), keanggotaan Jerman dalam Uni Eropa juga mengharuskan Jerman untuk mendukung kebijakan pertanian bersama (Common Agricultural Policy) dimana proyek lingkungan menjadi salah satu komitmennya (Wilson \& Wilson 2001). Jerman adalah salah satu negara yang menyumbang dukungan finansial lebih besar daripada negara lain di Uni Eropa untuk menyukseskan proyek ini (Wilson \& Wilson 2001).

Pemerintah Jerman menganggap pertanian organik sebagai salah satu prioritas. Ini ditunjukkan dengan kebijakan Agrarwende di tahun 2001. Kebijakan ini didorong oleh kejadian epidemi penyakit sapi, karenanya pemerintah ingin meningkatkan skema perlindungan konsumen dengan struktur industri pangan dan standar jaminan pangan. Kebijakan ini berusaha mengubah arus produksi pangan di Jerman yang mulanya bersifat industrial menjadi produksi yang memprioritaskan kualitas. Agrarwende dilakukan dengan memberikan dukungan institusional dan insentif ekonomi pada petani organik (Schafer et.al 2006).

\section{Budidaya Anggur di Jerman}

Di Jerman bukti budidaya anggur ditunjukkan dengan jejak 28 kebun anggur dari Bangsa Romawi di wilayah Mosel dan Rhine yang tercatat berasal dari abad ke 3 dan 5 Masehi (Dohnalovà 2018; König 2001). Secara kultural, budidaya, produksi dan konsumsi anggur memang lekat dengan orang Romawi dan Yunani. Pada perkembangan agama Kristen, anggur menjadi simbol penting dalam praktik keagamaan. Menurut para peneliti (diringkas dalam tulisan Unwin 1996) perdagangan anggur dipengaruhi oleh kejadian dan krisis dari masa ke masa. Pada permulaan abad 20, selain produksi massal anggur terjadi juga krisis serangan hama serangga ( hyloxerra) dan banyaknya penggunaan timbal ( $\mathrm{PbO})$ untuk menghentikan proses fermentasi. Selain itu produksi anggur massal mereplikasi penampilan anggur bereputasi tinggi sehingga konsumen tidak dapat membedakan anggur yang betul-betul berkualitas tinggi dan anggur mengalami penurunan harga karena adanya produksi massal sehingga mendorong terbentuknya sistem penentuan predikat dan kualitas anggur.

Secara ringkas, budidaya anggur berkembang selama berabad-abad dan menjadi bagian dari kehidupan masyarakat mulai dari budidaya, pembuatan anggur, maupun konsumsinya. Pembuatan anggur yang mulanya dilakukan untuk memenuhi kebutuhan gereja dan masyarakat borjuis berkembang dan dilakukan untuk memenuhi kebutuhan pasar. Hal ini berakibat pada sistem perdagangan anggur khususnya dengan adanya pengaturan kualitas untuk mengatasi melimpahnya produksi anggur. Hal ini dilakukan supaya tetap ada pembedaan harga anggur. Di sisi lain, pendapat mengenai kualitas anggur terbaik juga berkembang. Kualitas anggur tidak hanya dilihat dari tempat dimana anggur tersebut tumbuh, namun juga bagaimana detail dalam proses produksi anggur tersebut.

\section{Lahan Petani Jerman}

Petani Jerman menganut sistem Realteilung dimana lahan perkebunan dibagikan sama-rata pada setiap ahli waris (khususnya berkembang di Jerman bagian Barat Daya dan Selatan). Sistem pewarisan tanah ini mempengaruhi pola persebaran kepemilikan lahan perkebunan. 
Akibatnya, seorang kepala keluarga tani hanya memiliki lahan perkebunan yang relatif sempit (Wilson \& Wilson 2001). Hal ini menyebabkan petani kesulitan untuk bekerja secara efisien dan menghasilkan produk yang kompetitif di pasar (Mayhew 1970; Wilson \& Wilson 2001).

Pandangan tersebut menjadi salah satu perhatian negara sejak Perang Dunia I dan Perang Dunia II ketika terjadi krisis pangan. Petani menjadi kelompok penopang untuk menyediakan sumber pangan bagi tentara dan masyarakat urban yang goncang akibat perang (Wilson \& Wilson 2001). Meskipun demikian, pada tahun 1950-1960 terjadi tren urbanisasi dan deagrarianisasi dimana petani beralih profesi ke sektor industri. Ketika ekonomi industri mengalami peningkatan, sektor pertanian mengalami ketertinggalan. Pemerintah memberikan subsidi dan melakukan berbagai usaha perbaikan sistem pertanian (Wilson \& Wilson 2001).

Persoalan politik mendorong Jerman melakukan integrasi dengan negara-negara Eropa melalui pembentukan European Economic Community (ECC) untuk kepentingan keamanan. Salah satu agenda ECC adalah rencana kebijakan pertanian bersama di kalangan negara-negara ECC, Common Agricultural Policy (CAP). Kebijakan-kebijakan CAP ditujukan untuk melindungi petani-petani Eropa atas adanya liberalisasi pasar. Liberalisasi pasar sebetulnya dipandang oleh Persatuan Petani Jerman (DBV) menimbulkan kerugian bagi petani karena akan melemahkan posisi petani Jerman (Wilson \& Wilson 2001). Jerman sendiri melakukan proteksi ekonomi pada petani dengan tarif, penetapan harga komoditas pertanian agar petani dapat berhadapan dengan fluktuasi harga akibat kompetisi di pasar bebas (Wilson \& Wilson 2001).

Proteksi dan perlindungan petani dilakukan dengan mengubah posisi petani dalam struktur sosial. Jerman meromantisir nilai-nilai Jerman Barat dengan menempatkan petani sebagai pilar masyarakat untuk melegitimasi langkah politik internasionalnya (Wilson \& Wilson 2001). Salah satu kebijakannya adalah 'Green Plan' (Alexander 1964) yang dilakukan dengan flurbereinigung (konsolidasi lahan), aufstockung (perluasan ukuran kebun), aussiedlung (pemindahan lokasi pertanian). Program ini dilakukan dengan mendanai secara langsung petani melalui pemberian kredit sejak tahun 1957. Restrukturisasi dan konsolidasi lahan juga dibarengi dengan pembangunan infrastruktur pertanian secara besar-besaran oleh pemerintah. Pemerintah Jerman mengeluarkan biaya besar untuk membiayai konsolidasi lahan, pembangunan infrastruktur pertanian, subsidi petani, pinjaman untuk petani, uang ganti rugi dan pensiun untuk petani (Mayhew 1968).

\section{Gerakan Lingkungan di Jerman dan Biodinamik}

Keprihatinan masyarakat Eropa terhadap lingkungan didorong oleh situasi lingkungan dan kesejahteraan sosial. Kemunculan kesadaran ini berasal dari aspek teologi kristiani dan aspek sains dan teknologi. Pada prosesnya, penyebaran terjadi melalui media massa, organisasi sosial, dan partai politik. Sebagai contoh, sebuah surat kabar dengan bahasa Finlandia membahas manajemen air dan perlindungan hewan. Menurut Lahtinen dan Vuorisalo (2005), hal ini merupakan asal muasal gerakan lingkungan di Eropa dan kemunculan organisasi lingkungan. Gerakan peduli lingkungan ini yang dipandang sebagai respon atas industrialisasi dan komunisme yang dianggap gagal dalam melindungi lingkungan dan melakukan pemerataan distribusi kekayaan (Dominick 1998). Selain 
itu, gerakan lingkungan ini juga melahirkan Partai Hijau yang sadar ekologis dan merepresentasikan persoalan lingkungan di negara maju di Belanda dan Norwegia (Rootes 2008).

Pada kalangan akar rumput, petani pun turut berpartisipasi dalam kegiatan yang berkaitan dengan isu lingkungan. Secara spesifik, petani mengkritik gerakan pertanian konvensional yang dianggap merusak lingkungan, dan menawarkan suatu cara bertani baru yang dipandang dapat menimbulkan lebih sedikit dampak negatif terhadap lingkungan. Salah satu sistem produksi khususnya produksi anggur ramah lingkungan adalah pertanian biodinamik.

Institusi yang menjadi media penyebaran teknik bertani biodinamik adalah Demeter, organisasi penjamin kualitas pangan yang berdiri di Eropa pada 1928. Demeter menyatakan bahwa sertifikasi menandakan permulaan dari pertanian berkelanjutan 'modern'. Kemudian gerakan ini meluas dan berkembang hingga di tahun 1997 muncul Demeter Internasional yang diciptakan untuk mengawasi dan mengatur kerjasama hukum, ekonomi, dan nuansa spiritual dalam pertanian biodinamik di aras internasional (dalam Caldwell, 2012).

Sistem pertanian biodinamik menerapkan pendekatan spiritual yang melibatkan unsur kosmologis. Ia memiliki akar ideologis yang lahir dari gerakan religius baru yaitu Theosophy kemudian Anthroposophy. Anthroposophy merupakan komunitas yang diinisiasi oleh Rudolf Steiner yang memiliki paham religius yang diterapkan dalam berbagai aspek kehidupan seperti kesehatan, pendidikan serta pertanian. Dalam sektor pertanian, instruksi yang diberikan oleh Rudolf Steiner dimunculkan dari praktik spiritual bukan eksperimen spiritual. Sistem pertanian yang dianggap mengikuti ajaran religius ini telah dikaji dalam ilmu pengetahuan. Pertanian biodinamik dianggap memiliki hubungan dengan ilmu fisika kuantum dan biologi yang saat ini sedang ditelaah potensinya untuk peningkatan efisiensi pertanian (Wright, Kieft, von Diest, 2017).

Prinsip dalam pertanian anggur biodinamik di antaranya adalah pertama, implementasi pemikiran holistik secara konsisten. Pandangan holistik di sini menempatkan kebun atau lahan pertanian sebagai satu bagian dari alam. Kebun dianggap 'hidup' dan menjadi organisme unik yang dipengaruhi oleh zat-zat material, daya fisik alam juga daya kreatif dari kosmos. Pandangan ini diterapkan dalam praktik yang menjadikan kebun menjadi satuan dengan makhluk lain yaitu hewan ternak. Pangan ternak disediakan sendiri sehingga ternak dapat tumbuh dengan sehat. Ternak akan menghasilkan sumber pupuk yang akan menghasilkan kesuburan tanah untuk tanaman. Pertanian akan berkembang dan pemeliharaan ternak ini akan mendukung adanya produksi pangan. Penerapan diversifikasi kebun yang dianut dalam sistem biodinamik ini kemudian diharapkan dapat memunculkan harmoni kebun dengan habitat alam lainnya seperti serangga, burung, dan hewan lain. Oleh karena itu Demeter mengharuskan adanya pemeliharaan ternak (Demeter, 2014: 5).

Kedua, penggunaan preparasi untuk peningkatan kesuburan tanah. Preparasi dalam sistem pertanian biodinamik adalah salah satu bahan penting yang pembuatannya diatur secara spesifik. Pengaturan ini mulai dari bahan yang digunakan untuk menjadi preparasi, hingga cara pembuatan ramuan preparasi dan waktu aplikasi preparasi dalam tahapan budidaya. Preparasi ini khusus diwajibkan dalam sistem pertanian biodinamik untuk meningkatkan kesuburan tanah. Preparasi ini diberi kode nomor untuk setiap bahan yang digunakan yaitu 500 (kotoran sapi); 500P (Preparasi 500 dengan 502-507); 501 (Silika); kedua ramuan tersebut adalah senyawa tanah yang campurannya dicampur dalam air 
hangat sebanyak 40-60 liter dan diaduk selama satu jam yang arah sirkulasi aduknya diubah setiap dua menit. Setiap satu hektar lahan akan diberi ramuan sebanyak empat tanduk sapi. Ramuan humus 500 digunakan saat menabur dan pada tanah, sedangkan ramuan silika 501 digunakan untuk tanaman lain (Kirchmann, 1994). Selain itu, ada beberapa ramuan lain yang digunakan (lihat tabel 1$)$.

Tabel 1. Jenis-jenis ramuan yang diterapkan pada pertanian Biodinamik

\begin{tabular}{|l|l|}
\hline Jenis Ramuan & Kegunaan \\
\hline Ramuan 502 (Achillea millefolium) & $\begin{array}{l}\text { Berisi bunga daun seribu yang ditekan pada kandung kemin } \\
\text { rusa jantan merah. Campuran ini dijemur saat musim panas, } \\
\text { dimasukkan dalam tanah saat musim dingin, dan kemudian } \\
\text { dikubur saat musim semi. }\end{array}$ \\
\hline Ramuan 503 (Metricaria recutia) & $\begin{array}{l}\text { Terdiri dari bunga kamomil yang dimasukkan dalam lambung } \\
\text { sapi, dan kemudian dikubur di tanah yang kaya dengan humus } \\
\text { di musim gugur dan diambil saat musim semi. }\end{array}$ \\
\hline Ramuan 504 (Utrica dioica) & $\begin{array}{l}\text { Ditanamkan pada gambut dan diletakkan di tanah sepanjang } \\
\text { tahun. }\end{array}$ \\
\hline Ramuan 505 (Quercus robur) & $\begin{array}{l}\text { Berisi kulit kayu ek dicacah menjadi kecil dan diletakkan di } \\
\text { tulang hewan domestik, kemudian ditanam pada gambut } \\
\text { dan dikubur di tanah selama musim gugur di tempat di mana } \\
\text { banyak air hujan lewat. }\end{array}$ \\
\hline Ramuan 506 (Taraxacum officinale) & $\begin{array}{l}\text { Berisi bunga Dandelion yang ditekan dan ditempatkan di } \\
\text { selaput perut sapi yang dikubur di tanah pada musim dingin } \\
\text { dan diambil saat musim semi. }\end{array}$ \\
\hline Ramuan 507 (Valeriana offoconalis) & $\begin{array}{l}\text { Terdiri dari bunga valerian yang diekstrak dalam air sebanyak } \\
\text { satu sampai tiga gram. Di setiap campurannya, ditambahkan } \\
\text { pada pupuk organik dengan menempatkan pada tumpukan } \\
\text { pupuk di dalam lubang kira-kira } 50 \text { cm dalamnya dan diberi } \\
\text { spasi sejauh } 2 \text { meter. Kompos (kotoran sapi dengan preparasi } \\
\text { 502-507). }\end{array}$ \\
\hline
\end{tabular}

Ketiga, penting untuk mengetahui saat yang tepat dalam melakukan aktivitas kerja pertanian. Cara berpikir dalam pertanian dan pandangan hidup yang holistik menempatkan pertanian menjadi entitas yang tidak berdiri sendiri. Pergerakan bumi terhadap planet dan bintang lainnya dianggap memiliki kekuatan yang saling mempengaruhi. Oleh karena itu, momentum dalam melakukan aktivitas pertanian juga menjadi suatu aspek yang penting. Misalnya posisi bulan terhadap bumi yang akan memberikan pengaruh gravitasi yang akan mempengaruhi kondisi tanah dan perlakuan terhadap tanaman menjadi berbeda-beda (Demeter 2014: 5). Hal ini membutuhkan pengamatan yang teliti terhadap alam, tidak semua petani dapat melakukan hal ini. Untuk mempermudah dan memberikan pedoman pada petani biodinamik, tersedia kalender bulan seperti MoonworxLite, kalender Maria Thun, atau Stella Natura. Kalender ini dapat menunjukkan kapan waktu-waktu yang tepat untuk melakukan aktivitas kerja tani tertentu.

\section{Pengusaha Anggur di lhringen}

Ihringen memiliki sebutan sebagai "Desa Terhangat di Jerman" dan dikenal menjadi wilayah pertanian dan perkebunan dengan kualitas tinggi. Mayoritas penduduknya bekerja di sektor pertanian (petani sayur, anggur, pengusaha sektor pertanian, pengusaha anggur). Pengusahaan anggur menjadi sektor utama di kalangan masyarakat yang menjadi salah satu 
identitas kultural dengan kurang lebih dua puluh weingut (rumah anggur) yang memiliki beragam citra seperti anggur kualitas tinggi, anggur buatan keluarga, anggur lokal, anggur petani kecil, anggur dengan citarasa mineral dan citra lainnya.

Pengelolaan usaha rumah anggur di Ihringen terbagi menjadi tiga jenis. Pertama, rumah anggur yang dikelola oleh negara yakni Staatweingut yang dijadikan sebagai pusat penelitian dan pengembangan pengusahaan anggur. Kedua, rumah anggur yang lebih mirip seperti pabrik yang dikelola oleh koperasi yakni Winzergenossenschaft yang mendapatkan suplai anggurnya dari petani-petani anggur kecil di sekitar Ihringen. Ketiga, rumah anggur yang dikelola oleh keluarga atau disebut sebagai weingut. Rumah anggur negara dan koperasi petani anggur ini tergolong sebagai pengusahaan anggur skala besar, sementara rumah anggur tergolong sebagai pengusahaan anggur skala kecil.

\section{Jenis-Jenis Pengusahaan Anggur di lhringen}

Pengusahaan anggur di Ihringen yang dapat ditemui adalah petani anggur, koperasi petani anggur dan rumah anggur keluarga. Ketiganya dibedakan berdasarkan kegiatan pengusahaan yang dilakukan, produk usaha tani yang dihasilkan.

\section{Petani anggur}

Petani anggur adalah petani yang mengakses lahan baik dengan menyewa atau memiliki lahannya sendiri. Saat ini petani menggunakan berbagai macam mesin dan traktor untuk dapat meningkatkan efisiensi. Petani anggur di Ihringen sendiri dapat digolongkan menjadi petani kecil, menengah dan besar. Petani kecil mengelola lahan kurang dari 5 hektar, petani menengah mengelola kebun 5-10 hektar, dan petani besar mengelola kebun yang luasnya lebih dari 10 hektar. Kondisi petani anggur di Ihringen saat ini juga sudah berbeda dengan kondisi petani di masa sebelumnya dimana petani masih bergantung pada tenaga dan memiliki kebun dalam luasan yang relatif lebih sempit. Pada masa satu hingga dua generasi sebelumnya, petani masih menggunakan cangkul, peralatan manual dan berjalan kaki atau menggunakan kendaraan sederhana menuju kebun-kebun yang lokasinya jauh dari kawasan pemukiman.

\section{Koperasi petani anggur}

Koperasi petani anggur atau winzergenossenschaft adalah jenis pengusahaan anggur kedua di Ihringen. Secara historis koperasi tumbuh dari solidaritas petani anggur yang merasa senasib akan kondisi ekonomi mereka. Krisis ekonomi anggur akibat impor yang terjadi bersamaan dengan carut marut kondisi sosial politik di abad-19 menimbulkan pertumbuhan koperasi-koperasi anggur hampir di seluruh pusat-pusat perkebunan anggur Jerman (Schenk 1994: 188-192). Di Ihringen sendiri, munculnya koperasi dilandasi akan kesadaran untuk mengubah nasib petani. Dahulu, petani menjual anggur pada pengepul, akibatnya petani menjadi pihak yang paling dirugikan dalam proses produksi anggur. Kesadaran ini membuat petani di Ihringen bersama-sama membangun koperasi agar hasil panen petani bisa dihargai dengan lebih layak dengan cara melakukan pengelolaan bersama.

Pengelolaan bersama ini dilakukan dengan membangun usaha produksi anggur dengan status kepemilikan bersama dimana petani adalah anggota koperasi. Kata koperasi 
dalam bahasa Jerman winzergenossenschaft muncul dari asal kata genossen yang artinya adalah tempat yang sama, hak yang sama dan pemilik yang sama. Bersama-sama anggota koperasi membangun bangunan dan membeli mesin untuk dapat memproduksi anggur sendiri. Petani yang menjadi anggota koperasi wajib menjual anggur ke koperasi. Model koperasi semacam ini berkembang di setiap desa di Kaiserstuhl.

Koperasi petani anggur di Ihringen didirikan pada tahun 1924 dengan total 666 anggota. Anggota terdiri dari petani, pengelola koperasi, dan pengelola pengolahan anggur. Luas lahan yang tercatat di koperasi Ihringen adalah 311 hektar. Dari total lahan tersebut, hanya ada sepuluh petani yang memiliki lahan seluas 10-15 hektar. Ratusan petani lainnya hanya mengelola kebun yang luasnya kurang dari setengah hektar dan karenanya menjadikan aktivitas budidaya anggur sebagai hobi (umumnya mereka memiliki profesi sebagai pekerja industri di luar kota). Harga anggur ditentukan oleh beratan anggur, kandungan gula dan kapan panen dilakukan, namun perkiraan harga anggur rata-ratanya adalah $65 \mathrm{sen} / \mathrm{kg}$. Produktivitas rata-rata petani anggota koperasi adalah $120 \mathrm{~kg} / \mathrm{are}$. Petani juga dapat menjual anggur setelah diproses menjadi sari perasan anggur yang dihargai 80 sen/liter. Seorang petani yang menggantungkan diri menjual hasil panen anggur untuk dapat bertahan hidup membutuhkan paling tidak kebun seluas 20 hektar.

Koperasi petani anggur ihringen adalah rumah anggur dengan produktivitas paling tinggi. Hal ini sejalan dengan orientasi koperasi tersebut yang adalah produktivitas tinggi. Koperasi menggunakan berbagai macam mesin yang dapat memproduksi anggur dalam skala besar secara efisien. Setiap tahun, koperasi memproduksi sekitar 3.000 .000 botol anggur yang dihargai 3 euro hingga 14 euro per botol. Jenis anggur yang diproduksi adalah anggur merah, putih, rose, dry, sweet, dan half dry. Anggur merah adalah yang paling banyak diproduksi karena popularitasnya dan produk koperasi dijual di supermarket dan diekspor.

\section{Rumah anggur keluarga}

Rumah anggur keluarga adalah jenis pengusahaan anggur ketiga di Ihringen. Model pengusahaan anggur keluarga adalah model pengusahaan anggur yang paling dominan di Ihringen. Terdapat hampir dua puluh rumah anggur keluarga di Ihringen. Rumah anggur tertua misalnya berdiri sejak 1880-an. Kemudian pada tahun 1990-muncul lebih banyak rumah anggur keluarga baru. Rumah anggur keluarga pada dasarnya adalah pengusahaan anggur berbasis keluarga. Kegiatan produksi yang dilakukannya meliputi budidaya anggur, fermentasi anggur hingga pemasaran dan penjualan anggur.

Berbeda dengan koperasi yang memiliki citra sebagai anggur pabrikan, umumnya rumah anggur keluarga memperkenalkan diri mereka sebagai produksi artisan, bereputasi tinggi, dikerjakan dengan manual. Rumah anggur keluarga melakukan branding produknya dengan berbagai aspek dalam produksi. Mulai dari lokasi kebun, teknik budidaya, proses fermentasi, tradisi pembuatan anggur keluarga dan seterusnya. Keanggotaan rumah anggur dalam organisasi-organisasi elit seperti VDP atau Gault Milau juga turut mempengaruhi citra rumah anggur. Sebagai bisnis yang dijalankan keluarga, pewarisan rumah anggur menjadi penting. Rumah anggur yang dikelola dari satu generasi ke generasi berikutnya menunjukkan adanya pemegangan tradisi atau pewarisan keterampilan dalam memproduksi anggur. Dalam pengusahaan anggur, identitas rumah anggur amat penting. 
Salah satu jenis rumah anggur keluarga adalah Rumah Anggur Meyer.

\section{Praktik Pengusahaan Anggur Biodinamik di Rumah Anggur Meyer}

Pengusahaan anggur ramah lingkungan mulanya muncul di tahun 1980-an. Rumah anggur Meyer adalah salah satu perintis pembudidayaan anggur dengan prinsip-prinsip organik. Rumah anggur Meyer didirikan sejak tahun 1984 oleh Gisela dan Claus Meyer. Claus adalah seorang lulusan kehutanan Universitas Freiburg. Sebagai perintis, Claus dan Gisela membutuhkan banyak dukungan untuk mempelajari cara pengusahaan anggur yang menerapkan prinsip-prinsip ramah lingkungan. Tidak hanya tantangan itu, rumah anggur Meyer pun perlu bertahan untuk menjalankan bisnis. Gisela berasal dari Ihringen, namun selepas sekolah ia bekerja di Selandia Baru di sektor pertanian dan bertugas membantu petani. Menurut cerita Gisela, saat itulah ia menyadari kecintaannya pada dunia pertanian. Oleh karena itu, ia kembali ke kampung halamannya di Ihingen. Pada saat ini ia bertemu dengan Reinhold yang berasal dari Stuttgart dan kuliah di jurusan kehutanan Universitas Freiburg. Pada masa- masa studinya, waktu yang ia habiskan di Ihringen digunakan juga untuk mempelajari produksi anggur.

Pada akhirnya, keduanya memutuskan untuk menikah dan membangun bisnis rumah anggur keluarga mereka sendiri. Gisela bercerita, pada 1984 ia dan suaminya jengah melihat orang-orang disekelilingnya yang hanya ingin menghasilkan uang dan keuntungan yang menurutnya muncul sebagai akibat dari krisis perang dunia. Petani dan pengusahaan anggur pada saat itu cenderung ingin menumpuk keuntungan melalui budaya monokultur. Orientasi akan produktivitas ini menimbulkan kerusakan lingkungan seperti penurunan kesuburan tanah, berkurangnya biodiversitas alam, dan polusi air. Dengan bertani anggur secara organik, Gisela berharap bisa berkontribusi pada usaha untuk melestarikan lingkungan dan ingin menunjukkan pada petani-petani lainnya bahwa sistem yang berkelanjutan mungkin dilakukan dalam menjalankan pengusahaan anggur.

Rumah Anggur Meyer mengumpulkan modal melalui kredit bank dengan pelunasan cicilan lebih dari 20 tahun, dana dari investor sebesar 300.000 Euro, dan perjanjian hutang dengan pemilik tanah untuk menyewa lahan. Berbagai keperluan yang dibutuhkan adalah membeli dan menyewa lahan, membeli mesin dan alat produksi, membeli hewan ternak dan melakukan kegiatan usaha. Gisela dan Reinhold mempelajari bagaimana membudidayakan anggur dan memproduksi anggur dengan bergabung di komunitas-komunitas petani dan organisasi petani Bioland (label organik di Jerman). Untuk menjalankan usahanya, mereka menggunakan tenaga mereka sendiri dan mempekerjakan buruh tani. Gisela dan Reinhold menginginkan Rumah Anggur Meyer membuka kesempatan untuk pekerja yang membutuhkan dan memiliki hubungan yang hangat dengan pekerjanya. Terlepas dari keinginan tersebut, pekerja dan buruh tani diberikan upah sesuai dengan ketentuan hukum ketenagakerjaan, menanggung pajak keselamatan kerja, dan mempekerjakan sesuai standar jam kerja.

Untuk mencegah kegagalan panen akibat gulma, penggunaan mesin mekanik lebih dianjurkan ketimbang menggunakan herbisida. Tantangan lain yang dihadapi adalah lokasi yang dekat dengan lembah Sungai Rhein dan iklim yang cenderung hangat, sehingga pembudidayaan anggur menjadi lebih rentan pada pertumbuhan jamur sebagai hama yang 
akan merusak anggur. Hingga tahun 2020, petani belum menemukan solusi yang lebih efisien daripada penggunaan semprotan fungisida yang mengandung tembaga di dalamnya. Pada prinsip pertanian ramah lingkungan penggunaan fungisida sendiri dibatasi karena dampak jangka panjangnya terhadap kesuburan tanah. Tembaga juga adalah jenis material yang tidak mudah terurai dalam tanah. Oleh karena itu lembaga-lembaga pengontrol pertanian ramah lingkungan (termasuk regulasi Uni Eropa, Bioland, Ecovin, Naturland, dan Demeter) membatasi penggunaan fungisida yang kandungan tembaganya maksimal $3 \mathrm{~kg} /$ hektar/ tahun.

Tantangan utama yang dihadapi petani anggur ramah lingkungan adalah masifnya hama 'jamur' dan longgarnya regulasi atas penggunaan fungisida yang sering kali membingungkan. Menurut keluarga Meyer, pelonggaran penetapan standar penggunaan fungisida dengan menghitung batasan setiap tiga tahun cukup membantu karena fluktuasi cuaca yang berubah-ubah setiap tahunnya. Batasan penggunaan yang disetujui lembaga terhadap fungisida sebesar $15 \mathrm{~kg} /$ hektar setiap tiga tahun. Selain pemerintah melalui lembaga penelitian yang mengetahui tantangan hama dan penggunaan fungisida belum dapat diatur secara ketat. Akan tetapi bibit anggur hibrida yang resisten terhadap hama jamur atau disebut dengan 'Piwi' mulai dikembangkan sebagai solusi.

Dengan dikembangkannya bibit Piwi, petani dapat mengurangi penggunaan fungisida. Di sisi lain, bibit anggur jenis ini pun adalah jenis baru yang tidak banyak dikenal oleh konsumen penikmat anggur yang menyebabkan pengusaha anggur memiliki tantangan dalam penjualan. Hal ini serupa dengan anggur organik atau ramah lingkungan lainnya, pengusaha anggur masih kesulitan. "Konsumen anggur akan lebih memilih anggur jenis burgundy atau Pinot“ ungkap Gisela (wawancara Desember 2018).

Untuk dapat mengatakan bahwa anggur tersebut 'organik', produsen anggur dapat menggunakan sertifikat organik. Sertifikasi tersebut dikeluarkan oleh lembaga sertifikasi seperti Naturland, Biolad dan Ecovin. Lembaga-lembaga ini bekerjasama dengan lembaga kontrol A.B.Cert, yang berperan dalam melakukan kontrol kualitas produk dengan melakukan pengecekan nota belanja, kontrol ke kebun, kilang anggur. Dengan nota belanja, kontroler dapat melakukan tes laboratorium lanjutan apabila diperkirakan pembelian fungisida lebih daripada standar maksimal.

Kandungan zat kimia dalam anggur sendiri dapat menjadi persoalan karena lokasi lahan yang berdekatan dengan kebun-kebun anggur konvensional lainnya. Ada risiko di mana semprotan pestisida atau fungisida dari kebun konvensional tertiup ke kebun organik. Di sisi lain, untuk menyewa satu lokasi kebun tersendiri yang tak terkena pestisida atau fungisida akan memakan biaya yang cukup besar.

Pada tahun 2013, anak Gisela dan Claus yang bernama Tobias, memberikan ide untuk mengubah pengusahaan anggur organik menjadi biodinamik. Tobias memperoleh pengetahuan ketika menjadi asisten peneliti doktoral di Universitas Geissenheim. Dalam penelitiannya, ia membandingkan metode budidaya anggur konvensional, organik dan biodinamik. Tobias bercerita, di tanah yang dikelola secara biodinamik ditemukan lebih banyak hewan-hewan kecil. "Aku melihat sendiri bahwa di kebun yang dikelola secara biodinamik, tanahnya memiliki lebih banyak cacing dan hewan-hewan kecil lainnya ketimbang kebun konvensional dan organik" (wawancara dengan Tobias, Januari 2019).

Tobias membantu pengelolaan dan pemrosesan anggur di rumah anggur Meyer karena sudah terbiasa sejak kecil diajak bermain ke kebun dan di masa remaja membantu 
orangtuanya. Pada tahun 2017, rumah anggur Meyer resmi dikelola oleh Tobias. Pada praktik budidaya anggur, keluarga Meyer menggunakan varietas yang diperbolehkan oleh negara dan varietas persilangan yang resisten dari hama jamur. Selain itu, di kebun juga digunakan preparasi biodinamik. Preparasi ini dibuat dengan tahap khusus dan dipercayai dapat menjadi salah satu metode penghubung misalnya tanah dengan daya tarik benda langit. "Sapi dipercaya sebagai hewan yang memiliki daya tarik paling kuat dengan benda langit karena ia memiliki banyak lambung", kata Gisela. Proses pembuatan ramuan yang akan dimasukkan dalam tanduk sapi, dilakukan dengan mengaduk dalam tong selama satu jam dengan arah jarum jam. Metode ini disebut sebagai metode homeopathy, "homeopathy diyakini sebagai bentuk transmisi, seperti berkomunikasi, sehingga energi yang timbul pada proses peramuan, mampu menjadi pendorong keanekaragaman hayati di tanah" (wawancara dengan Tobias, Januari 2019).

Kendala-kendala penerapan prinsip-prinsip biodinamik yang dihadapi rumah anggur Meyer adalah risiko kontaminasi, batasan penggunaan semprotan tembaga, dan pengaturan waktu dalam kerja-kerja pertanian. Risiko kontaminasi pestisida menjadi tinggi akibat lokasi kebun keluarga Meyer yang terpencar dan berisiko terkena pestisida dari kebun konvensional yang berada di sekitar kebun mereka. Konsekuensi dari lokasi kebun yang terpencar juga mempengaruhi pengaturan waktu yang sesuai dengan kalender bulan untuk mengikuti hari akar, hari buah, hari daun dan seterusnya. Kedua kendala tersebut, masih dapat diatasi karena mereka tidak perlu betul-betul mengikuti kalender bulan dan risiko kontaminasi pestisida belum melebihi batas minimal. Akan tetapi, yang paling menyulitkan keluarga Meyer adalah batasan penggunaan semprotan tembaga untuk melindungi tanaman anggur dari hama jamur (3 kg/hektar/tahun). Sedangkan, sistem kontrol yang dilakukan Demeter selain melakukan inspeksi ke kebun langsung adalah mengontrol nota belanja. Dalam nota belanja ini dapat ditemukan seberapa besar penggunaan semprotan tembaga tanpa tes laboratorium yang memakan waktu dan rumit.

Pada proses fermentasi anggur, pengrajin anggur harus mengontrol suhu, mengatur jumlah perasan anggur, ragi, kandungan gula, menghentikan proses fermentasi. Dalam prinsip biodinamik, zat-zat tambahan seperti perasa dilarang penggunaannya. Pengrajin anggur dituntut untuk mengontrol kualitas rasa anggur dari keahlian yang dimiliki.

Rumah anggur Meyer juga bergabung dalam berbagai organisasi misalnya organisasi pemberi jasa persewaan mesin dan organisasi petani anggur muda. Keanggotaan dalam organisasi-organisasi ini membantu rumah anggur Meyer untuk terhubung dan mendapatkan informasi seputar pengusahaan anggur seperti informasi pelaksanaan festival anggur, informasi mengenai perubahan cuaca, dan informasi mengenai pencegahan risiko gagal panen akibat cuaca.

Rumah Anggur Meyer turut menjadi anggota dalam Demeter dimana para anggota dapat bertukar produk dan informasi untuk memenuhi kebutuhan sebagai produsen pangan. Misalnya, Tobias yang tidak memelihara sapi dapat membeli tanduk sapi untuk membuat preparasi biodinamik dari anggota lain dalam organisasi ini. Selain Demeter, terdapat beberapa label anggur ramah lingkungan lain yang dapat dipertanggungjawabkan kualitasnya, yakni Bioland dan Naturland. Label tersebut sangat menentukan verifikasi produk ramah lingkungan di Jerman. Produksi massal terjadi pasca perluasan perdagangan produk ramah lingkungan. Awalnya, di Freiburg pada tahun 1980an hanya ada lima toko kecil. Sekarang produk ramah lingkungan mudah ditemui di supermarket. Akibatnya, toko 
dan usaha kecil yang melayani produk ramah lingkungan pun tutup. Awalnya, perluasan perdagangan produk ramah lingkungan ini dipelopori golongan muda yang menganggap bahwa distribusi melalui toko-toko kecil akan menghabiskan terlalu banyak tenaga, waktu, dan energi. Namun, distribusi ke supermarket ini berdampak pada meningkatkan kompetisi rumah produksi ramah lingkungan..

Produk anggur ramah lingkungan tidak hanya berasal dari Jerman, namun juga dari negara-negara di Eropa lainnya. Penjualan anggur ramah lingkungan menjadi sangat kompetitif di pasar. Gisela berpendapat konsumen seharusnya tahu bahwa produk ramah lingkungan dari Jerman memiliki standar yang lebih ketat dan berbeda dengan standar di negara lain. Misalnya, pembatasan penggunaan semprotan tembaga di Jerman sebanyak $3 \mathrm{~kg} / \mathrm{h}$ ektar/tahun sementara di Prancis sejumlah $6 \mathrm{~kg} / \mathrm{hektar} / \mathrm{tahun}$. Dengan dua standar nasional yang berbeda tersebut, masing-masing produk sudah dapat mendapatkan label ramah lingkungan. Bagi Gisela, penting untuk konsumen mengetahui perbedaan standar ini.

Penjualan anggur ramah lingkungan merupakan salah satu yang menjadi tantangan pengusahaan anggur. Rumah anggur perlu membangun reputasi di kalangan konsumen agar produknya dikenal dengan ciri khas tertentu. Rumah anggur Meyer memperkenalkan produk mereka melalui promosi di festival-festival, sosial media dan seterusnya. Agar dapat memperoleh keuntungan lebih, Rumah Anggur Meyer berperan sebagai produsen sekaligus distributor dari anggur mereka sendiri. Peta berikut adalah bagaimana rumah anggur Meyer mendistribusikan produk anggur mereka.

Peta 1. Ilustrasi distribusi produk Rumah Anggur Meyer

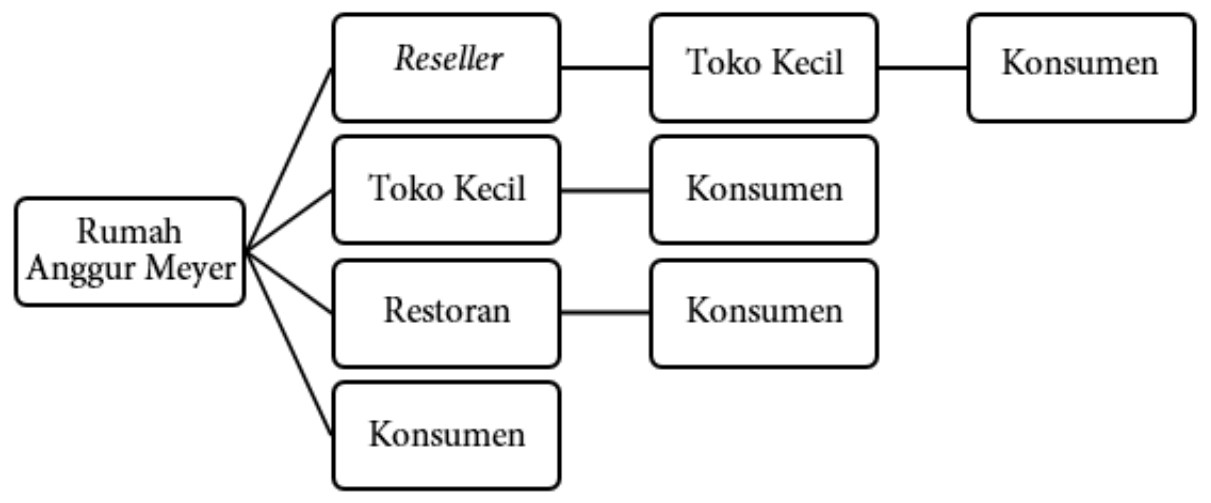

Rumah Anggur Meyer mencoba berbagai cara untuk menjual anggur dengan bekerjasama toko besar yang mengambil anggur setiap bulan ke rumah anggur, mengantarkan anggur ke toko-toko, dan menjual anggur pada konsumen langsung. Keuntungan yang diperoleh distribusi melalui toko besar atau reseller adalah tidak adanya biaya antar dan jumlah botol anggur yang didistribusikan lebih banyak. Di sisi lain, Distribusi melalui toko-toko kecil akan membutuhkan biaya antar dan jumlah anggur yang dititipkan lebih sedikit. Pada tiap-tiap proses penjualan, Rumah Anggur Meyer menentukan harga yang berbeda-beda. Harga anggur untuk konsumen langsung adalah harga yang paling tinggi. Akan tetapi, pekerjaan membutuhkan layanan tambahan. 
Konsumen disuguhi cerita mengenai proses produksi anggur, pencicipan anggur yang bisa memakan waktu lebih lama apabila pencicipan dilakukan dengan makanan penyanding. Paling tidak dibutuhkan waktu hingga satu jam untuk memberikan layanan tersebut. Apabila dibandingkan, jumlah botol yang dijual pada konsumen langsung dengan reseller adalah 5:50, sehingga tetap jumlah yang terjual tidak sebanyak ketika menjual pada reseller. Menurut Gisela, pada akhirnya semua cara untuk menjual anggur tetap dilakukan karena masing-masing cara memiliki kelebihan dan kekurangannya masing-masing.

Gisela menyatakan bahwa ia telah menunjukkan bahwa pengusahaan anggur yang ramah lingkungan mungkin dilakukan. Semenjak rumah anggur Meyer berdiri hingga saat ini, pengusahaan anggur berjalan dengan baik, meski tentu perlu usaha yang besar untuk membangunnya hingga sebesar sekarang. "Jika bisa lebih baik, mengapa tidak?" (wawancara, 20 Desember 2018) adalah salah satu dorongan Gisela untuk beralih dari pertanian organik ke biodinamik. Tobias juga menyatakan, "praktik biodinamik, khususnya label Demeter adalah label yang proses kontrolnya paling ketat di Jerman, dan memiliki reputasi yang tinggi." (wawancara, 27 Januari 2019).

Dengan demikian, praktik biodinamik terbukti dapat meningkatkan kesuburan tanah dan memperkaya kehidupan mikroba. Oleh karena itu, usaha yang dirintis oleh kilang anggur Meyer, untuk melakukan praktik ramah lingkungan yang mereka kembangkan dengan terus mewacanakan bahwa prinsip pertanian biodinamik "lebih baik daripada pertanian organik“. Menjadi upaya meningkatkan reputasi anggur yang diproduksi.

\section{Kesimpulan}

Pengusahaan anggur biodinamik, bukanlah praktik pengusahaan anggur yang dominan di Desa Ihringen. Praktik ini diawali dengan praktik pertanian ramah lingkungan muncul sejak dekade 1980-an melalui sistem pengusahaan organik dan mulai berkembang dengan cara biodinamik di tahun 2013. Sistem yang sifatnya ramah lingkungan ini diharapkan mengembalikan kesuburan tanah. Kendati demikian, hingga kini, masih ada variasi pengusahaan anggur berupa praktik konvensional, organik dan biodinamik. Praktik ramah lingkungan bukanlah praktik yang dilakukan oleh mayoritas petani di Ihringen karena petani konvensional memandang sistem tersebut kurang menguntungkan dengan lebih banyaknya tenaga dan biaya produksi yang diperlukan.

Di Ihringen pertanian ramah lingkungan dengan praktik organik membawa sistem baru yaitu sistem produksi berbasis biodinamik yang menggunakan pendekatan efektivitas energi kosmis dalam proses produksi. Dalam praktiknya yang kompleks seperti penggunaan tanduk rusa dalam pembuatan kompos, praktik biodinamik dianggap sebagai praktik yang berasal dari sistem kepercayaan terhadap ajaran Rudolf Steiner. Oleh karena itu, petani konvensional menganggap praktik biodinamik sebagai praktik yang lebih rumit, lebih banyak risiko dan lebih banyak kerja yang harus dilakukan, terlebih biaya lebih yang harus dibayarkan untuk membayar sertifikasi penjamin kualitas pengusahaan anggur biodinamik.

Bagi pengusaha anggur biodinamik sendiri, penerapan pengusahaan anggur biodinamik masih bersifat parsial. Tanaman anggur yang rentan terhadap jamur dan bergantung pada penggunaan fungisida belum dapat diatasi oleh sistem ini. Petani biodinamik masih bergantung pada penggunaan tembaga untuk melindungi tanaman. Pengusaha anggur yang menerapkan praktik biodinamik meyakini dapat berkontribusi 
pada usaha menjaga kelestarian alam. Kepada lingkungan, mereka mencoba menunjukkan bahwa pengusahaan ramah lingkungan dapat dilakukan dan tetap dapat menguntungkan secara ekonomis. Kepada konsumen, praktik-praktik dalam pengusahaan anggur mereka seperti menghindari penggunaan input kimia, menggunakan sertifikasi Demeter, menjadi tolok ukur nilai bahwa anggur yang diproduksi adalah anggur yang ramah lingkungan yang dibuat oleh rumah anggur keluarga. Praktik dan cara pengusahaan anggur baik dalam cara membudidayakan anggur serta di gudang bawah tanah ini mengekspresikan nilai-nilai mereka dalam usaha untuk berkontribusi pada wacana ekonomi berkelanjutan.

\section{Referensi}

Alexander, D. (1964). Some Features of West German Policy for Improving Agricultural Structure. Journal of Farm Economics, 46 (4), 791-804.

Demeter. (2013, December). A Guide for Biodynamic Winegrowing. Darmstadt.

Dominick, R. (1998). Capitalism, Communism, and Environmental Protection: Lessons from the German Experience. Environmental History, 3 (3), 311-332.

Donahlovà, R. (2018). Weinfeste in Deutschland. Tradition und Gegenwart in Bad Dürkheim. Pardubice: The University of Pardubice. Faculty of Philosophy.

Guthman, J. (2000) Agrarian Dreams? The Paradox of Organic Farming in California. Berkeley: University of California.

Guthman, J. (2008). Neoliberalism and the Making of Food Politics in California. Geoforum, 39, $117-1183$.

Kirchman, H. (1994). Biological Dynamic Farming: An-Occult Form of Anternative Agriculture? Journal of Agricultural and Environmental Ethics, 7 (2), 173-187.

König, V. M. (2011). Die spätantike Agrarlandschaft an der Mosel II: Weinbau und Landwirtschaft. Vol. (33), 96-102.

Legras, J., Merdinoglu, D., Cornuet, J., \& Karst, F. (2007). Bread, beer and wine: Saccharomyces cerevisae diversity reflects human history. Molecular Ecology, 16, 2901-2102.

Li, T. M. (2007). Practices of assemblage and community forest management. Economy and society, 36 (2), 269-293.

Mayhew, A. (1970). Structural Reform and the Future of West German Agriculture. Geographical Review, 60 (1), 54-68.

McMahon, N. (2005). Biodynamic Farmers in Ireland. Transforming Society Through Purity, Solitude, and Bearing Witness? . Sociologia Ruralis 45 (1/2), 98-114.

Mercile, J. (2016). Neoliberalism and the Alcohol Industry in Ireland. Space and Polity, 20 (1), 59-74.

Rootes, C. (2008). The Environmental Movement. In M. Klimke, \& J. Scarloth, 1968 in Europe: A History of Protest and Activism (pp. 295-306). New York \& Hampshire: Palgrave Macmillan.

Rudig, W. (1988). Peace and ecology movements in Western Europe. Western European Politics, 11 (1), 26-39.

Schafer, M., Ulmer, H., Engel, A., Kantelhardt, J., \& Heißenhuber, A. (2006). National Agricultural Policy: the German Agrarwende. In G. Holt, M. Reed, \& (ed), Sociological Perspectives of Organic Agriculture (pp. 272-283). UK: CAB International. 
Schenk, W. (1994). The role of regional vinters' cooperatives in the development of rural areas in Germany. Journal of Wine Research, 5 (3), 187-203.

Schieren, J. (2011). The scientific credibility of anthroposofy. Research in Steiner Education 2 (2), 90-98.

Segal, R. (2010). Myth and Ritual. In J. Hinnels, The Routledge Companion to Study of Religion (pp. 372-396). New York: Routledge.

Staudenmaier, P. (2011). Facist Ecology: The "Green Wing" of the Nazi Party and Its Historical Antecedents. In P. Staudenmaier, \& J. Biehl, Ecofasism Revisited: Lessons from German Experience (pp. 13-42). Posgrunn: New Compass Press.

Stein, R., \& Stein, P. (2017). The Anthropology of Religion, Magic, dan Witchcraft. New York: Routledge.

Unwin, T. (1996). Wine and the Vine: An Historical Geography of Viticulture and the Wine Trade. London \& New York: Routledge.

Wilson, G., \& Wilson, O. (2001). German Agriculture in Transition: Society Policies and Environment in a Changing Europe. New York: Palgrave. 